\title{
Factors Influencing Involvement in Nonfarm Income Generating Activities Among Local Farmers: The Case of Ughelli South Local Government Area of Delta State, Nigeria
}

\author{
Bishop O. Ovwigho ${ }^{1}$ \\ ${ }^{1}$ Department of Agricultural Economics and Extension, Delta State University, Nigeria \\ Correspondence: Bishop O. Ovwigho, Department of Agricultural Economics and Extension, Delta State \\ University, Asaba Campus, Asaba, Delta State, Nigeria. E-mail: bishopvwigho@yahoo.com
}

Received: December 22, 2013 Accepted: January 23, 2014 Online Published: January 25, 2014

doi:10.5539/sar.v3n1p76

URL: http://dx.doi.org/10.5539/sar.v3n1p76

\begin{abstract}
The study investigated the factors influencing the involvement of farm families in non farm income generating activities. Multi - stage and stratified simple random sampling procedures were used to compose the sample. The sample was made up of seventy two (72) heads of rural farm families. Data were collected by use of structured interview schedule and Focus Group Discussion. Data were analysed by simple percentage, Chi square test, multiple regression and correlation There was a significant relationship between number of non farm income generating activities and demographic characteristics $\left(R^{2}=0.870\right)$. Farm size $(t=-2.386 ; p=0.020)$, level of education $(t=-4.227 ; \mathrm{p}=0.00)$, and household size $(\mathrm{t}=5.404 ; \mathrm{p}=0.00)$ were significant and constant predictors of number of non farm income generating activities engaged in by the farm families. A significant relationship was found between involvement in non farm income generating activities and soil degradation due to infertility $\left(X^{2}=23.66, p<0.01\right)$ and oil spillage $\left(X^{2}=26.01, p<0.01\right)$. The study established a linear relationship between number of income generating activities and demographic characteristics. Extension workers should take into cognisance all rural income generating activities engaged in by the farm families when embarking on services and programmes aimed at improving their welfare.
\end{abstract}

Keywords: rural income generating activities, rural nonfarm activities, secondary income generating activities, heads of rural farm families, rural area

\section{Introduction}

\subsection{Background Information}

Several studies have shown that farmers particularly the rural farm families usually engage in different nonfarm or off-farm income generating activities ostensibly to obviate the seasonality of primary agricultural production and create a continuous stream of income to cater for the starring exigencies of life. Secondary or nonfarm income generating activities refer to those incomes earned by the farmer from nonfarm income generating activities at different times of the year. The land mark study by Barrett et al. (2001) and Carletto et al. (2007) exemplified that diversification was the norm among rural farmers in Africa. They noted that very few people collect all their income from any one source, hold all their wealth in the form of any single asset, or use their assets in just one activity. Multiple motives prompt households and individuals to diversify assets, incomes, and activities. According to World Bank (2003), Lanjouw and Lanjouw (2001) and Meludu et al. (1999) rural households world-wide engage in a variety of nonfarm activities to generate income. The engagement in multiple income generating activities is peculiar to rural farming communities in Africa. The major off-farm income generating activities which the farmers engaged in included food processing, trading, mat weaving and pottery.

The types of off-farm income generating or rural non-farm activities vary across geo-political locations and countries. This explains the apparent difficulties in the classification and delineation of the effects of off-farm income generating activities on welfare of farmers. Lanjouw and Feder (2001) noted that much of the observed variation among countries in the share of rural non-farm activities stems from weaknesses in the data being used. First, for many countries the data are outdated or missing altogether. For others, the only available data were case studies of limited geographical coverage, and thus not nationally representative. For those countries for which 
employment data were available from population censuses, reported rates were most likely underestimated since they often only accounted for rural non-farm activities when they were the primary occupation. For many rural households, rural non-farm activities were only a secondary or even tertiary source of income, and as such, go unreported in census data. Although an increasing numbers of developing countries carry out nationally representative surveys, the available evidence on rural income shares remains scanty (Lanjouw \& Feder, 2001).

The available data indicated the importance of rural non-farm economy. In general, there is considerable variation across countries. For Latin America and the Caribbean, estimates of rural non-farm income shares for rural households range from $22 \%$ in Honduras to $59 \%$ in Costa Rica and $68 \%$ for Haiti (Reardon et al., 2001). For Africa, estimates range between 15\%, for Mozambique to $93 \%$, for Namibia (Reardon, 1997). Even more recent data for Eastern Europe and the CIS indicated a range from 31\% in Armenia to $68 \%$ in Bulgaria (Davis, 2004).

Rural Income Generating Activities (RIGA) covers all the income generating activities in the rural areas. Off-farm or Secondary income generating activities are aspects of RIGA. Thus, it has become a misnomer o use the term occupation to describe the income generating activities of rural farmers. However, it is plausible to describe an individual as a farmer if the predominant income and activity is concerned with primary production (fisheries, crop and livestock husbandry). This is because many rural farmers during data collection usually agreed that they were farmers without mentioning their involvement in off-farm income generating activities.

\subsection{Statement of the Problem}

According to Khandker (1995) pervasive poverty affected millions of people in Bangladesh at many levels, and its alleviation required diverse measures. The most important interventions were those which provided employment and income generation opportunities to the rural poor, and enabled them enhance their living standards. The government has made poverty alleviation one of its primary concerns in various development plans and has made continued efforts to obtain foreign assistance in agriculture, forestry, fisheries, education, health and nutrition sectors. Khan (2001) found that rural poverty accounts for nearly 63 percent of poverty worldwide, reaching 90 percent in some countries like Bangladesh, and 65 to 90 percent in sub-Saharan Africa (exceptions to this pattern are several Latin American countries in which poverty is concentrated in urban areas).

Carletto et al. (2007) stated that rural non-farm activities were often countercyclical with agriculture and as such might serve as a consumption smoothing or risk insurance mechanism, particularly when the returns to these activities were not highly-correlated with agricultural returns, and might also absorb excess labour during agricultural off-peak periods. Given the small-scale, informal and home-based nature of some rural non-farm self-employment activities, they were often heralded as a promising strategic complement to agriculture for rural poverty alleviation.

According to Micevska and Rahut (2008) recent research indicated that the rural poor engaged in nonfarm activities, both as a complement to their farm activities and as a substitute for their farm incomes. In some cases, nonfarm employment may be a coping strategy to deal with lack of access to sufficient land or with income shocks in agriculture. In other cases, rural households may find it profitable to reduce their farming activities and engage increasingly in nonfarm employment.

Lanjouw and Lanjouw (2001) and Akinsanmi (1994) reported that rural households in Africa, especially the poor, often lack access to key agricultural inputs and to the markets necessary

to achieve an agricultural-led pathway out of poverty. They noted that in West Africa and farmers were considered to occupy the lowest ranks in society. Their skills do not receive the public recognition accorded those of other professions. People in white-collar jobs often have a higher standard of living than the average farmer. Olaitan (1984) observed that the village farmers who produce the crops sold in urban markets, towns and villages were usually very poor. He remarked that the middlemen appear to be wealthier hence it was financially preferable to be a distributor of farm produce rather than a producer.

The foregoing juxtaposed the inherent poverty among rural farm families in spite of their involvement in multiple income generating activities. Previous studies confirmed that rural farm households engage in several income generating activities but the polemic was tackled from the perspectives of inequality and motives without considering the factors influencing involvement in nonfarm income generating activities by rural poor farmers. For instance, Senadza (2011) found that aggregate nonfarm income increased income inequality among rural households in Ghana. In terms of its components, while non-farm self-employment income reduced income inequality, non-farm wage income increased income inequality. 
Barrett et al. (2001) classified the motives for involvement in nonfarm income generating activities into two sets. The first set of motives comprise what were traditionally termed "push factors": risk reduction, response to diminishing factor returns in any given use, such as family labour supply in the presence of land constraints driven by population pressure and landholdings fragmentation, reaction to crisis or liquidity constraints, high transactions costs that induce households to self-provision in several goods and services. The second set of motives comprise "pull factors": realization of strategic complementarities between activities, such as crop-livestock integration or milling and hog production, specialization according to comparative advantage accorded by superior technologies, skills or endowments.

This study was designed to measure the factors influencing farmers' involvement in nonfarm income generating activities. The specific objectives were to:

i. Describe the demographic characteristics of the respondents;

ii. Collate the secondary income generating activities of rural farm families in the study area;

iii. Ascertain the relationship between number of secondary income generating activities and demographic characteristics of the respondents; and

iv. Investigate the influence of soil degradation on number of secondary income generating activities.

\section{Methodology}

\subsection{Description of the Study Area}

Ughelli South Local Government Area is one of the twenty five (25) Local Government Areas in Delta State, Nigeria. Its headquarters are in the city of Otujeremi. It has an area of $786 \mathrm{~km}^{2}$ and a population of 213,576 at the 2006 census. Delta State lies roughly between longitudes $5 \hat{\mathrm{A}}^{\circ} 00$ and $6 \hat{\mathrm{A}}^{\circ} 45^{\prime} \mathrm{E}$ and latitudes $5 \hat{\mathrm{A}}^{\circ} 00$ and $6 \hat{\mathrm{A}}^{\circ} 30^{\prime} \mathrm{N}$. It has a total land area of 16,842 sq. $\mathrm{km}$. The states bordering Delta State are Edo to the north, Ondo to the northwest, Anambra to the east and Bayelsa and Rivers to the southeast. On its southern flank is $160 \mathrm{~km}$ of the coastline of the Bight of Benin (Wikipedia, 2013).

\subsection{Sampling Procedure and Sample Size}

Multi - stage and stratified simple random sampling procedures were used to compose the sample. In the first stage, three (Ughievwen, Ewu and Olomu) out of the six clans in the Local Government Area were randomly selected. The second stage involved delineation of the rural areas. The rural areas were identified using the degree of rurality stratification measures as suggested by Ovwigho and Ifie, (2009). Towns and villages which do not have the presence of a public secondary School, maternity/clinic/hospital, hotel accommodation, police station, modern market and communication facilities were regarded as rural areas. Thirty three (33) rural areas were identified from the three clans based on these criteria. The surveys were carried out in these areas only. The third stage involved collation of the sampling frame which consisted of seven hundred and twenty (720) registered farmers. Ten per cent of the registered famers which corresponded to Ughievwen (30), Ewu (22) and Olomu (20) were randomly selected. Thus the sample was made up of seventy two (72) heads of rural farm families.

\subsection{Method of Data Collection}

Structured interview schedule and Focus Group Discussion were used in data collection. The interview schedule measured socio-economic characteristics, nonfarm income generating activities, and influence of land degradation on income activities. In the latter, respondents were asked to indicate if land degradation in the form of erosion/flood, soil infertility, over grazing, bush burning and oil spillage have prompted them to engage in nonfarm income generating activities.

\subsection{Measurement of Variables}

A list of secondary income generating activities in the study area was collated from pre-research survey and farmers were asked to indicate the ones they were engaged in as nonfarm or off-farm means of livelihood. Farm size was measured by the number of plots $(100 \mathrm{ft}$ by $50 \mathrm{ft}$ or $30.48 \mathrm{~m}$ by $15.24 \mathrm{~m})$; level of education was measured by the number of years spent in formal education; membership of cooperative society was measured by yes (1) or no (2) dichotomous response; household size was measured by the number of persons living in the household; and farming experience and age were measured in years. Soil degradation factors which cause the involvement of the farmers in multiple income generating activities were measured by yes (1) or no (2) dichotomy in the study area most of the farmers were illiterate and made use of plots in delineating farm size. A plot was converted to 0.05 hectares. 


\subsection{Method of Data Analysis}

The Statistical Package for Social Scientists (SPSS Version 20) was used in data analysis. Percentage and mean were used to analyse the demographic characteristics. Multiple correlation and regression analyses were used to achieve the relationship between number of income generating activities and demographic characteristics. Pearson's Chi square test was used to analyse the influence of soil degradation on number of income generating activities.

\section{Results and Discussion}

\subsection{Demographic Characteristics of Respondents}

The demographic characteristics of the respondents were presented in Table 1.

Table 1. Description of demographic characteristics of respondents

\begin{tabular}{lllll}
\hline Demographic Characteristics & $\mathrm{N}$ & Mean & Std. Deviation & Variance \\
\hline Farm size (Ha) & 72 & 0.9160 & 0.42533 & 0.181 \\
Level of education (years) & 72 & $12 \mathrm{yrs}$ & 3.75978 & 14.136 \\
Membership of cooperative society & 72 & 1.00 & 0.50039 & 0.250 \\
Household size & 72 & 6 & 2.80718 & 7.880 \\
Farming experience ( years) & 72 & 17 & 5.82167 & 33.892 \\
Age ( years) & 72 & 46 & 9.93704 & 98.746 \\
Valid N listwise & 72 & & & \\
\hline
\end{tabular}

The mean farm size was about 18 plots equivalent of 0.9160 ha. In Nigeria, the rural farms are characterised by small scattered farm holdings. The mean year of education was about 12 years. This meant that majority of the respondents had secondary education. Membership of cooperative society was $55.60 \%$ or 1 per respondent. The mean household size, farming experience and age were 6 family members, 17 years and 46 years respectively.

\subsection{Nonfarm Income Generating Activities}

The types of nonfarm or secondary income generating activities engaged in by the respondents were presented in Table 2 . The average number of secondary income generating activities engaged in by a farmer was found to be approximately 3 . The predominant secondary income generating activities were casual labour $(52.78 \%)$, fish traps/baskets weaving (38.89\%), transportation business $(29.17 \%)$, hunting game animals $(25.00 \%)$, traditional dancing/singing (20.83\%), lumbering/fuel wood vendor (15.28\%), and night guards (13.89\%).

These findings support the views of Oladeji (2007) and Okoye (1995) that even though farming was the predominant activity in most rural areas, farmers usually engage in supplementary or complementary activities during off-season periods. These supplementary activities include weaving, smithery, tannery, basketry, mat-making, carving, brass casting, wine tapping, hair dressing, petty trading, medical practice, driving, money lending, bicycle and shoe repairing. In this study, it was found that some of these nonfarm income generating activities were carried out simultaneously during farming season while others were carried out only during off-season periods. For example hunting game animals, dancing and singing, local pomade preparation, night guard, fruit gathering, casual labour, rubber tapping, palm wine tapping and processing, lumbering/fuel wood vendor, and casual labour were carried out simultaneously with farming activities. Other nonfarm income generating activities including brick layer, cement block moulding, transportation business, fish traps/baskets weaving, local gin distillation, carpentry and sculptural designs were mostly carried out during off-seasons. 
Table 2. Distribution of secondary income generating activities among respondents

\begin{tabular}{|c|c|c|c|}
\hline $\mathrm{S} / \mathrm{N}$ & Type of Secondary Income Generating Activities & No (Yes) & Per cen \\
\hline 1 & Brick layer & 7 & 9.72 \\
\hline 2 & Cement Block Moulding & 5 & 6.94 \\
\hline 3 & Petty trading/hawking of Agricultural Produce & 8 & 11.11 \\
\hline 4 & Sedentary palm kernel cracking & 2 & 2.78 \\
\hline 5 & Fish traps/baskets weaving & 28 & 38.89 \\
\hline 6 & Cane chair weaving & 1 & 1.39 \\
\hline 7 & Traditional Orthopaedic Doctor & 2 & 2.78 \\
\hline 8 & Transportation business & 21 & 29.17 \\
\hline 9 & Local gin distillation & 3 & 4.17 \\
\hline 10 & Contractor & 7 & 9.72 \\
\hline 11 & Palm oil processing & 9 & 12.50 \\
\hline 12 & Rubber tapping & 1 & 1.39 \\
\hline 13 & Rubber processing & 1 & 1.39 \\
\hline 14 & Casual Labour & 38 & 52.78 \\
\hline 15 & Fruit gathering & 7 & 9.72 \\
\hline 16 & Night guards & 10 & 13.89 \\
\hline 17 & Palm wine tapping & 5 & 6.94 \\
\hline 18 & Divination/traditional medicine/massaging & 4 & 5.56 \\
\hline 19 & Lumbering/fuel wood vendor & 11 & 15.28 \\
\hline 20 & Carpentry & 3 & 4.17 \\
\hline 21 & Hunting game animal & 18 & 25.00 \\
\hline 22 & Canoe carving & 3 & \\
\hline 23 & Sculptural design & 1 & 1.39 \\
\hline 24 & Traditional Dancing/Singing & 15 & 20.83 \\
\hline \multirow[t]{2}{*}{25} & Making of local pomade & 2 & 2.78 \\
\hline & Average number of income generating activities & 2.94 & \\
\hline
\end{tabular}

Though the respondents claimed farming as occupation it was difficult to establish a persons' occupation as farming because of the numerous income generating activities carried out by farmers all year round in the study area. The problems of developing a data base for rural income generating activities were compounded by population censuses which collect information only on the primary occupation, with consequent under reporting of secondary activities (Carletto et al., 2007). In Bangladesh, the commonest non farm income generating activities among the rural women were pisiculture, grocery, basket/rope making, leather goods making, vegetable/fish selling, saree/utensil selling, rice husking, tailoring and bakery (Parvin et al., 2004). In a similar study Oladeji (2007) identified eighteen secondary income generating activities in Imo State of Nigeria. These included basket weaving, food vendor, hair plaiting, petty trading, tailoring, collection of forest products, hired labour, black smithing, clothes weaving, carpentry, palm-tapping, welding, barbing, teaching, motor cycle (Okada) riding, brick layer, traditional medicine and transportation. Oladeji et al. (2006) identified hair plaiting, hired labour, soap making, milk processing and mat weaving as the major secondary income generating activities among Fulani women in Oyo State of Nigeria.

This study was quite unique in that local orthopaedic Doctor (setting of broken bones and massaging), traditional dancing/singing, sedentary palm kernel cracking, canoe carving, cement block moulding and divination have not been found as nonfarm income generating activities among farmers by other researchers on this subject.Ovwigho and Ifie (2009) admonished that it was more plausible to use the term income generating activities instead of 
occupation to describe the jobs done by rural peoples. This was because rural people engaged in more than one income generating activities because of the large scale subsistence and seasonality of agricultural production. In the view expressed by Carletto et al. (2007) the outcome of economic growth on the agricultural and rural non-farm (RNF) sector cannot be determined a priori. It was therefore useful, when thinking about rural development, to think of the full range of rural income generating activities (RIGA), both agricultural and non agricultural, carried out by rural households. This could allow an understanding of the relationship between the various economic activities that take place in the rural space and of their implications for economic growth and poverty reduction. From a policy perspective, the challenge was how to assure that the growth of the RNF "sector" could best be harnessed to the advantage of poor rural households and how to identify the mechanisms to best exploit synergies across agricultural and non agricultural sectors. The crux of the study, therefore, was to stimulate development intervention agencies to develop strategies for harnessing rural income generating activities for benefits of the rural farmers.

\subsection{Number of Secondary Income Generating Activities and Demographic Characteristics}

The relationship between number of income generating activities and selected demographic characteristics were analysed and presented in Tables 3 and 4.

Table 3. Coefficients of the multiple regression analysis

\begin{tabular}{|c|c|c|c|c|c|}
\hline \multirow[t]{2}{*}{ Model } & \multicolumn{2}{|c|}{$\begin{array}{l}\text { Unstandardized } \\
\text { Coefficients }\end{array}$} & \multirow{2}{*}{$\begin{array}{c}\text { Standardized } \\
\text { Coefficients } \\
\text { Beta }\end{array}$} & \multirow[t]{2}{*}{$\mathrm{T}$} & \multirow[t]{2}{*}{ Sig. } \\
\hline & B & Std. Error & & & \\
\hline (Constant) & 2.391 & 1.040 & & 2.300 & .025 \\
\hline Farm size & -.923 & 0.387 & -.168 & -2.386 & .020 \\
\hline Level of Education & -.222 & .052 & -.357 & -4.227 & .000 \\
\hline Membership of cooperative society & .423 & .297 & .091 & 1.424 & .159 \\
\hline Household size & .290 & .054 & .349 & 5.404 & .000 \\
\hline Farming Experience & .024 & .028 & .059 & .831 & .409 \\
\hline Age & .025 & .016 & .104 & 1.582 & .118 \\
\hline
\end{tabular}

$\mathrm{R}^{2}=0.870$

a. Dependent Variable: Number of nonfarm income generating activities.

Table 4. Multiple correlations between number of income generating activities and selected demographic characteristics

\begin{tabular}{cccccccc}
\hline Variables & Var 1 & Var 2 & Var 3 & Var 4 & Var 5 & Var 6 & Var 7 \\
\hline Var 1 Income Gen Activities & 1.00 & & & & & & \\
Var 2 Farm Size & $-0.723^{* *}$ & 1.00 & & & & & \\
Var 3 Education & $-0.848^{* *}$ & $0.752^{* *}$ & 1.00 & & & & \\
Var 4 Cooperative & $0.684^{* *}$ & $-0.557^{* *}$ & $-0.645^{* *}$ & 1.00 & & & \\
Var5 Household size & $0.790^{* *}$ & $-0.447^{* *}$ & $-0.622^{* *}$ & $0.531^{* *}$ & 1.00 & & \\
Var 6 Experience & $0.707^{* *}$ & $-0.586^{* *}$ & $-0.656^{*}$ & $0.473^{* *}$ & $0.590^{* *}$ & 1.00 & \\
Var 7 Age & $.647^{* *}$ & $-0.445^{* *}$ & $-0.487^{*}$ & $0.543^{*}$ & $0.593^{* *}$ & $0.651^{* *}$ & 1.00 \\
\hline
\end{tabular}

** correlations are significant at 0.01 ( 2 tailed test).

The multiple regression analysis showed that there was a significant relationship between the number of income generating activities and demographic characteristics $\left(R^{2}=0.870\right)$. This meant that all the independent variables were good predictors of number of income generating activities of the rural farm families. However, in Table 3 , farm size $(\mathrm{t}=-2.386 ; \mathrm{p}=0.020)$, level of education $(\mathrm{t}=-4.227 ; \mathrm{p}=0.00)$, and household size $(\mathrm{t}=5.404 ; \mathrm{p}=$ 0.00 ) were significant and constant predictors of number of income generating activities engaged in by the farm 
families. The correlations between all the variables were presented in Table 4. There was a significant and negative correlations between number of income generating activities, farm size $(r=-0.723)$ and level of education $(r=-0.848)$. There was positive and significant relationship between number of income generating activities and household size $(r=0.790)$.

Barrett et al. (2001), Kydd (2002), Reardon et al. (2006) and Wanyama (2010) and Senadza (2011) stated that income diversification among farmers involved adding income-generating activities including livestock, crop, non-farm and off-farm activities. They indicated that the activities generate a set of income portfolios with different degrees of risk, expected returns, liquidity and seasonality. The processes involved allocation of household productive assets among different income generating activities.

It was found that the smaller the farm size and lower the level of education of the farmer, the higher the numbers of nonfarm income generating activities of the farmer. These findings support the views of Reardon et al. (2001) that nonfarm activities seems to offer a pathway out of poverty if nonfarm opportunities could be seized by the rural poor. Zezza et al. (2007) noted that governments and donor agencies are attempting to tackle the non income dimensions of poverty through education and access to basic amenities.

The study also vindicates that the higher the household size, higher is the number of nonfarm income generating activities. The latter has a great implication for farm families in rural Africa where population control is a matter of semantics and where children are used for farm labour. Micevska and Rahut (2008) concluded that household assets, household characteristics, and location characteristics played important roles in explaining participation in nonfarm activities..

\subsection{Number of Secondary Income Generating Activities and Land Degradation}

The respondents were ask to tick yes or no against five causes of soil degradation which prompted their involvement in multiple income generating activities. The relationship was analysed by the use of Pearson Chi square test and presented in Table 5. A significant relationship was found between number of nonfarm income generating activities and soil degradation due to soil infertility $\left(X^{2}=23.66, r=0.57, p=0.009\right)$, crude oil spillage $\left(X^{2}=26.01, r=0.60, p=0.004\right)$, and bush burning $\left(X^{2}=48.31, r=0.82, p=0.000\right)$. Effects of soil degradation due to erosion/flood $\left(X^{2}=15.45, r=0.46 . p=0.116\right)$, and overgrazing $\left(X^{2}=7.34, r=0.32, p=0.693\right)$ were not significant. The study area is not prone to overgrazing and perennial erosion/flood.

Table 5. Relationship between number of income generating activities and soil degradation

\begin{tabular}{lccc}
\hline \multicolumn{1}{c}{ Variables } & Chi Square & Cramer's V & Significant \\
\hline $\begin{array}{l}\text { Effect of soil degradation due to infertility on } \\
\text { multiple income generating activities }\end{array}$ & 23.66 & 0.57 & 0.009 \\
$\begin{array}{l}\text { Effect of soil degradation due to crude oil } \\
\text { spillage on multiple income generating activities }\end{array}$ & 26.01 & 0.60 & 0.004 \\
$\begin{array}{l}\text { Effect of soil degradation due erosion/flood on } \\
\text { multiple income generating activities }\end{array}$ & 15.45 & 0.46 & 0.116 \\
$\begin{array}{l}\text { Effect of soil degradation due to bush burning } \\
\text { on multiple income generating activities }\end{array}$ & 48.31 & 0.82 & 0.000 \\
$\begin{array}{l}\text { Effect of soil degradation due to overgrazing on } \\
\text { multiple income generating activities }\end{array}$ & 7.34 & 0.32 & 0.693 \\
\hline
\end{tabular}

Soil degradation made majority of the farmers to engage in multiple income generating activities ostensibly to obviate the short fall in income during the off-farming season. The number of income generating activities is positively related to the frequency and degree of land degradation. The soil degradation influence on the number of secondary income generating activities is intrinsically related to the push factor motives described by Barrett et al. (2001).

Olawoye (2001), Oladeji (2007), and Shiferaw and Holden (2001) explained that in many agriculture-based poor economies soil erosion and degradation of agricultural land present a threat to food security. They maintained that declining per capita, availability of cultivable land, accompanied by lack of technologies for intensification of land use, force rural people to either expand farming into marginal erodible slopes or the remaining forest. Oladeji (2007) found that land degradation changes led to decrease in crop planting and in gathering of forest 
products. However he found that petty trading usually increase where there was land degradation. Reich et al. (2011) stated that land degradation has caused progressive decrease in the performance of the land. They maintained that where populations were low shifting cultivation and transhumance pastorals were able to circumvent declining productivity. They noted that with the increasing population these practices were no longer possible.

\section{Conclusion and Recommendation}

Previous studies merely highlighted the involvement of farmers in nonfarm income generating activities without establishing the relationship between the number and demographic characteristics. This study established linearism between number of income generating activities and demographic characteristics of the respondents. The demographic factors which influence the number of income generating activities were level of education, farm size and household size. There was a significant relationship between number of income generating activities and some soil degradation factors namely soil infertility, crude oil spillage and bush burning. Similar studies should be conducted in other parts of the country for the purposes of collating and harnessing the nonfarm income generating activities for the socio-economic well-being of the rural farm families. The characteristically small farm size made many of the farmers to engage in nonfarm activities. The way out of the vicious cycle of poverty among rural farmers in the study area is to increase the scale of production of both primary and secondary income generating activities.

\section{References}

Akinsanmi, O. (1994). Senior Secondary Agricultural Science. London: Longman

Barrett, C. B., Reardon, T., \& Webb, P. (2001). Nonfarm Income Diversification and Household Livelihood Strategies in Rural Africa: Concepts, Dynamics, and Policy Implication. Working Paper, Cornell University, Ithaca New York: Center for the Study of Inequality.

Carletto, G., Covarrubias, K., Davis, B., Krausova, M., Stamoulis, K., Winters, P., \& Zezza, A. (2007). Rural Income Generating Activities in Developing Countries. Journal of Agricultural and Development Economics, 4(1), 146-193.

Davis, J. (2004). The Rural Non-farm Economy, Livelihoods and their Diversification: Issues and Options. Chatham, UK: Natural Resource Institute.

Khan, M. H. (2001). Rural Poverty in Developing Countries: Implications for Public Policy. Economic Issues, No. 2. Washington DC: International Monetary Fund. http://dx.doi.org/10.5089/9781589060067.051

Khandker, R. S., Khan, Z., \& Khalily, B. (1995). Sustainability of a Government Targeted. Credit Program: Evidence from Bangladesh. World Bank Discussion Papers. Washington D. C.: The World Bank. http://dx.doi.org/10.1596/0-8213-3516-2

Kydd, J. (2002). Agriculture and Rural Livelihoods: Is Globalization Opening or Blocking Paths Out of Rural Poverty? Agricultural Research and Extension Network, Network Paper 121.

Lanjouw, J. O., \& Lanjouw, P. (2001). The Rural Non-Farm Sector: Issues and Evidence from Developing Countries. Agricultural Economics, 26(1), 1-23. http://dx.doi.org/10.1111/j.1574-0862.2001.tb00051.x

Lanjouw, P., \& Feder, G. (2001). Rural Non-farm Activities and Rural Development: from Experience Towards Strategy. Rural Development Strategy Background Paper Washington, DC: The World Bank.

Meludu, N. T., Ifie, L. A., Akinbile, I, \& Adekoya, E. A. (1999). The Role ofWomen in Sustainable Food Security in Nigeria: A Case of Udu local Government Area of Delta State. Journal of Sustainable Agriculture, 15(1), 87-97. http://dx.doi.org/10.1300/J064v15n01_08

Micevska, M., \& Rahut, D. B. (2008). Rural Nonfarm Employment and Incomes in the Himilayas. Working Paper No. 205. New Dehli: Indian Council for Research on International Development.

Okoye, C. U. (1995). The Rural Economy and Community Banking in Nigeria. In E. C. Eboh, C. U. Okoye \& D. Ayichi (Eds.), Rural Development in Nigeria: Concepts, Processes and Prospects (pp. 200-215). Enugu: Auto-Century Publishing Company.

Oladeji, J. O. (2007). Effect of Land Degradation on Income Generating Activities of Farmers in Imo State, Nigeria. Journal of Economics and Rural Development, 16(1), 93-106.

Oladeji, J. O., Olujide, M. G., \& Oyesola, O. B. (2006). Income Generating Activities of Fulani Women in Iseyin Local Government Area of Oyo State. Studies of Tribes and Tribals, 4(2), 117-121. 
Olaitan, S. C. (1984). Agricultural Education in the Tropics. London: Macmillan.

Olawoye, J. E. (2001). Contemporary Research Interest and Problems Areas in Agricultural Extension and Rural Development. The Ibadan Extension Monograph Series (pp. 21-22). No. 2. Department of Agricultural Extension and Rural Development.

Ovwigho, B. O., \& Ifie, P. A. (2009). Principles of Youth Development in Africa. Benin-City: Ethiope Publishers.

Parvin, G. A., Ahsan, S. M. R., \& Chowdhury, M. R. (2004). Women Empowerment Performance of Income Generating Activities Supported by Rural Women Employment Creation Project (RWECP): A Case Study in Dumuria Thana, Bangladesh. The Journal of Geo-Environment, 4, 47-62.

Reardon, T. (1997). Using Evidence of Household Income Diversification to Inform Study of the Rural Nonfarm Labor Market in Africa. World Development, 25(5), 735-748. http://dx.doi.org/10.1016/S0305-750X(96)00137-4

Reardon, T., Berdegué, J., \& Escobar, G. (2000). Rural Nonfarm Employment and Incomes in Latin America: Overview and Policy Implications. World Development, 29(3), 411-425.

Reardon, T., Berdegué, J., Barrett, C. B., \& Stamoulis, K. (2006). Household Income Diversification into Rural Nonfarm Activities. In S. Haggblade, P. B. R. Hazell \& T. Reardon (Eds.). Transforming the Rural Nonfarm Economy (p. 34). Baltimore: Johns Hopkins University Press.

Reich, P. F., Numben, S. T. R.., Almara, A., \& Eswaran, H. (2011). Land Resource Stresses and Desertification. Proceedings of Second International Conference on Land Degradation and Desertification, Khon Kaen, Thailand: Oxford Press New Delhi.

Senadza, P. (2011). Does Non-farm Income Improves or Worsen Income Inequality? Evidence from Rural Ghana. African Review of Economic and Finance, 2(2), 104-121.

Shiferaw, B., \& Holden, S. T. (2001). Farm-Level Benefits to Investment for Mitigating Land Degradation: Empirical Evidence from Ethiopia. Journal of Economic Geography, 3(3), 335-358.

Wanyama, M. L., Mose, L. O., Odendo, M., Okuro, J. O., Owuor, G., \& Mohammed, L. (2010). Determinants of Income Diversification Strategies amongst Rural Households in Maize based Farming Systems of Kenya. African Journal of Food Science, 4(12), 754-763.

Wikipedia. (2013). Ughelli South. Retrieved from http://en.wikipedia.org/wiki/ughelli_south

World Bank. (2003). Reaching the Rural Poor: A Renewed Strategy for Rural Development. Washington, DC: The World Bank.

Zezza, A., Carletto, G., Davis, B., Stamoulis, K., \& Winters, P. (2007). Rural Income Generating Activities: Whatever Happened to the Institutional Vacuum? Evidence from Ghana, Guatemala, Nacaragua and Vietnam. ESA Working Paper No. 07-24.

\section{Copyrights}

Copyright for this article is retained by the author(s), with first publication rights granted to the journal.

This is an open-access article distributed under the terms and conditions of the Creative Commons Attribution license (http://creativecommons.org/licenses/by/3.0/). 